\title{
ОНТОЛОГИЈА У ФИЛОЗОФИЈИ И ИНФОРМАТИЦИ: ПОТЕНЦИЈАЛНА СИНТЕЗА НЕМОГУКЕГ
}

\begin{abstract}
Сажетак
Према неким мишљењима, онтологија представља основни део метафизике, филозофске области, а сам термин има значење „иза физике“. У концептуалним смислу, овај опис метафизике као „онога што је иза и даље од“ физике се често потеже. Метафизика се због тога схвата као изучавање, првих, крајњих и последњих ствари, а њен садржај иде иза физике или било које друге дисциплине. Према мишљењу Аристотела, Декарта и многих других, проблем узрока и супстанце, и анализа општих термина као што су потенцијалност и актуалност јесу примери појмова који могу добити дефинитиван третман само у општој дисциплини метафизике. Такође, веома је битно изучавање бића као таквог, док посебне науке изучавају посебне делове бића. Сам појам онтологија потиче од грчких речи онтос (биће) и логос (наука). Према томе, појам означава «науку о бићу» и односи се на онај огранак филозофије који изучава овај садржај.

Мада онтологија као филозофски концепт спада у теоретске теме, она се суштински веома много примењује у практичним апликацијама и информатици и информационим технологијама, као што је онтолошки инжењеринг. Онтологије се користе у вештачкој интелигенцији, семантичком вебу, софтверском инжењерству и приликом дизајна информационих архитектура, као облика представљања сазнања у одређеној области као целини, или неком од њених делова. Очекује се да ће онтологије и њихова примена у савременом технолошком свету имати веома значајну улогу у развоју информационо -комуникациионих технологија.
\end{abstract}

Кључне речи: онтологија, метафизика, семантички веб, информатика, вештачка интелигенција.

Чување и управљање нашег знања о свету или одређене области је веома стари подухват који датира од Аристотела и траје током целог 
развоја човечанства. Према Лексикону Милана Вујаклије дата је много

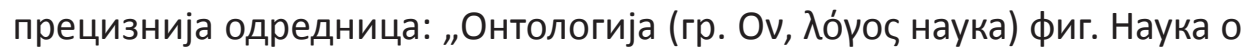
бићу, о ономе што постоји, основна наука, наука о општим својствима ствари и бића. Онтолошки (гр. Ov, 入о́үос који се тиче мишљења) фил. који се тиче онтологије или се оснива на њој; онтолошки доказ о бићу или постојању бога доказ постојања бога из појма бога као бескрајног или савршеног бића; онтолошки метод логички поступак који, ослањајући се на принцип противречности и принцип довољног разлога , хоће да на основу постојања појмова, закључују о постојању онога што ти појмови претстављају; уп. космолошки, физикотеолошки. У Википедији на српском језику порекло и значење речи је наведено је

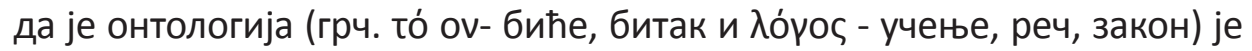
филозофска дисциплина која расправља о бићу као бивствујућем, као и о његовим општим, фундаменталним и конститутивним одређењима.

Реч онтологија се први пут појављује у филозофији и мада је етимологија из старогрчког језика, први пут се појављује на латинском, 1606. године у делу „Ogdoas Scholastica“ Јакоба Лорхарда - Лорхардуса ( Jacob Lorhard - Lorhardus) а затим 1613. године у „Lexicon philosophicum“ Рудолфа Гокела - Гокленијуса ( (Rudolf Göckel - Goclenius). Према другом извору Речнику филозофије наводи се :"Долази од грчких речи онтос («биће») и логос («наука»). Према томе, појам означава «науку о бићу» и односи се на онај огранак филозофије који изучава овај садржај. Термин није био познат пре 17. века, када га је у употребу увео Гокленијус, 1636. године, а затим су га користили Клобер 1647, Микраелиј 1653. и Духамел 1663. До краја века, након што су га прихватили Лајбниц, Волф и Баумгартен, термин се усталио у употеби. Упркос чињеници да термин има властиту историју коришћења, општи консензус о његовој употреби никада није постигнут. Однос између метафизикеи онтологијеостаоје врлонејасан. Клобер сматра онтологију «исходишном науком», која проучава биће као биће. Наука би требало да се подједнако усресреди на све ентитете, од бога до створених бића, и да буде и у основи теологије и физике. Наука треба да проучава особине и принципе бића, као и да анализира узрок, уређеност, однос, истину и савршенство. Он ју је назвао именом онтосопхиа, задржавајући исто значење као и онтологија, мада је радије користио властити термин. С временом су термини постали заменљиви“. Хусерл 
је разграничио формалну од садржајне онтологије, при чему се обе баве анализом суштина. Формална онтологија изучава формалну и универзалну суштину и представља коначно исходиште свих наука. Садржајна онтологија изучава садржајне и поједине суштине и основ је за све чињеничке науке. Садржајне онтологије су појединачне, а појединачне онтологије имају основ у формалној онтологији. Хајдегер сасвим супротно, сматра да онтологија проучава егзистенцију. Она анализира само «биће егзистенције» и открива границе егзистенције, а осим тога проучава шта егзистенцију чини уопште могућом.

Поменућемо Рене Декарта (René Descartes), којег Бранислав Петронијевић сматра не само за једног од највећих филозофа, него је и један од највећих математичара (основао је аналитичку геометрију, која геометријске количине своди на алгебарске) и (поред Аристотела и Лајбница) спада у један од највећих универзалних духова. Декартово чувено "cogito ergo sum» он објашњава: „Кад кажем: мислим, дакле постојим, то управо значи: мислим да постојим, свестан сам да постојим, дакле постојим. Тиме што додајем оно „дакле“ ја не изводим ништа ново што би било у ономе појму „мислим“, већ просто изражавам јасније сам садржај тог појма“. Петронијећев објашњава да Декартов основни став није некакв закључак већ једна непосредна интуитивна истина, у коју нико не може сумњати које само једном схватио њен смисао. И наравно да Декарт у свом обимном опусу, у делу „Пета медитација“ помиње онтолошки доказ и наводи : „У мени постоје многобројне идеје које морају бити истините по себи, па ма не имало ван мене никаквих ствари које би ми одговарале а то су идеје математичких објеката“. Појмом онтологије у филозофији су се бавили многи научници али се током историје десило на први поглед неспојиво, да се појам онтологије, наравно на сасвим други начин проучава и у рачунарству или прецизније рачунарској лингвистици.

Једна од научних области која је доста допринела томе је и развој вештачке интелигенције, при чему су изучаване различите врсте појава а међу њима и лексика, речници, опште онтологије и онтологије домена, таксономије и терминологије. Недавни развој и повећано интересовање за онтологије доводи и до различитих схватања и тумачења самих онтологија али и других семантичких извора. У ствари термин онтологија се користи веома често, тако да није увек јасно које су разлике међу многобројним врстама семантичких ресурса. 


\section{Онтологије у рачунарству}

У рачунарству и информатици онтологија је формално представљање скупа концепата унутар домена и релацијама између тих појмова, према Википедији на енглеском. Користи се за разумевање својстава домена а такође и за њихово описивање. У теорији, Том Грубер (Tom Gruber) је 1992. године дефинисао је кратко: „Онтологија су договори о дељеним концептуализацијама“ (An ontology is a specification of a conceptualization.) Односно, позната и општеприхваћена Груберова дефиниција онтологије као „формалне спецификације дељене концептуализације“ указује на онај вид знања које је могуће пренети, разменити и употребити. Бавио се углавном вештачком интелигенцијом са својим колегама је извео још неке закључке и навео да већина формално представљеног знања се заснива на концептуализацијама: објекти, концепти, као и други ентитети за које се претпоставља да припадају одређеној области а такође и односи који постоје међу њима. Онтологија је вид репрезентације знања. Уколико је онтологија дата на неком формалном језику и складишти се у формату који је рачунарски читљив реч је о формалној онтологији. Може да се представља као заједнички реперезантативни речник, који се користи за обликовање домена, врсту објеката и / или концепата који постоје, као и за опис а њихових особина и односа, у контексту дељења знања. Нешто касније 2009. године, Грубер наводи: „Онтологија се састоји од концепата са дефиницајама, њихове хијерархијске организације, односа између њих и аксиома којима се формализују дефиниције и односи." Онтологије се користе у научним областима као што су вештачка интелигенција, семантички веб, инжењерство система, програмирању, биомедицинској информатици, библиотекарству, моделирању послова, архитектури информација, представљању знања, развојне методологије, дељење знања и вишеструка употреба знања, менаџмент знања, систематизација домена знања, употреба информација са интернета, стандардизације и развоја, које се огледа у новим методологијама, језицима, алатима и компресијама. као што је представљање и ширење знања општег или специфичне научне области. Онтолошки инжењеринг се развија у новије време 
и обухвата скуп активности које се изводе током концептуализације, дизајна, имплементације и развоја онтологија.

Семантички веб је визија веба следеће генерације, која омогућава апликацијама да аутоматски прикупљају веб документа из различитих извора, интегришу и процесирају информације и сарађују са другим апликацијама да би извршиле софистициране задатке у корист људи. Семантички веб је проширење постојећег веба у ком су подаци дефинисани и повезани на начин који омогућава да ихмашине користе не само за потребе приказивања, већ и за аутоматизацију, интеграцију и поновно коришћење у разноврсним апликацијама. Дефиниција семантичког веба коју је дао Бернерс-Ли (Sir Timothy John «Tim» Berners-Lee): “Семантички веб је наставак, екстензија постојећег веба где је информацији дато прецизно дефинисано значење и који боље омогућава сарадњу између рачунара и корисника."

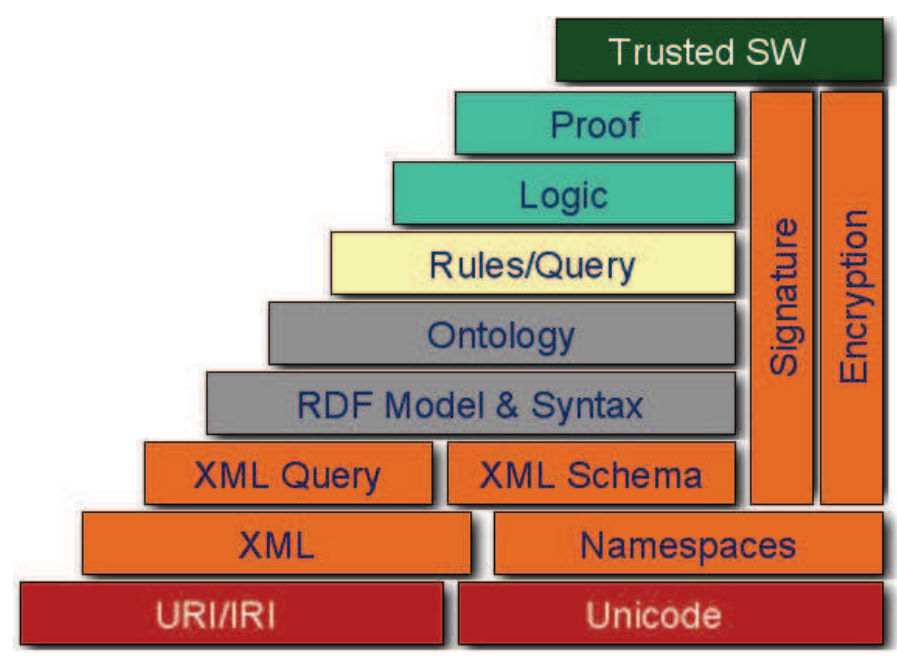

Слика 1. Семантички веб https://www.w3.org/RDF/Metalog/docs/sw-easy

Карактеристика слојевитости семантичког веба је у томе што је за изградњу нивоа „изнад“ мора користити слој „испод“. Виши слојеви (Logic, Proof i Trust), још увек су раним фазама развоја у погледу стандарда који се односе на семантички веб. Успешно креирање и функционисање онтологија на вебу врши се помоћу тзв. 
онтолошких језика, па су у овом раду описани слојеви „торте“ до нивоа онтолошког речника (енгл. Ontology Vocabulary). W3C (World Wide Web Consortium) је до сада прихватио следеће језике:

- RDF

- RDFS

- OWL (Web Ontology Language),

- XML (eXtensible Markup Language) и XMLS (XML Schema)

Оквир за дефинисање ресурса (Resource Definition Framework RDF) је W3C стандардни онтолошки језик, чији је циљ дефинисање механизама за опис ресурса на вебу, односно - дефинисање механизама за опис информација у вези било ког домена.

Прошириви језик за маркирање (енгл. eXtensible Markup Language - XML) је мета језик тј. језик за креирање језика за означавање, специфично оријентисан према једном типу садржаја. Језик за означавање користи ознаке које су директно уграђене у сам текст.

Weб онтолошки језик (енгл. Web Ontology Language - OWL) je језик за дефинисање онтологија на вебу.

\section{Features}

$\circ$ Mappings to all of WordNet

$\circ$ Language generation templates for Hindi, Chinese, Italian, German, Czech and English

- Tool support for browsing and editing

- Largest free, formal ontology available, with $\sim 25,000$ terms and $\sim 80,000$ axioms when all domain

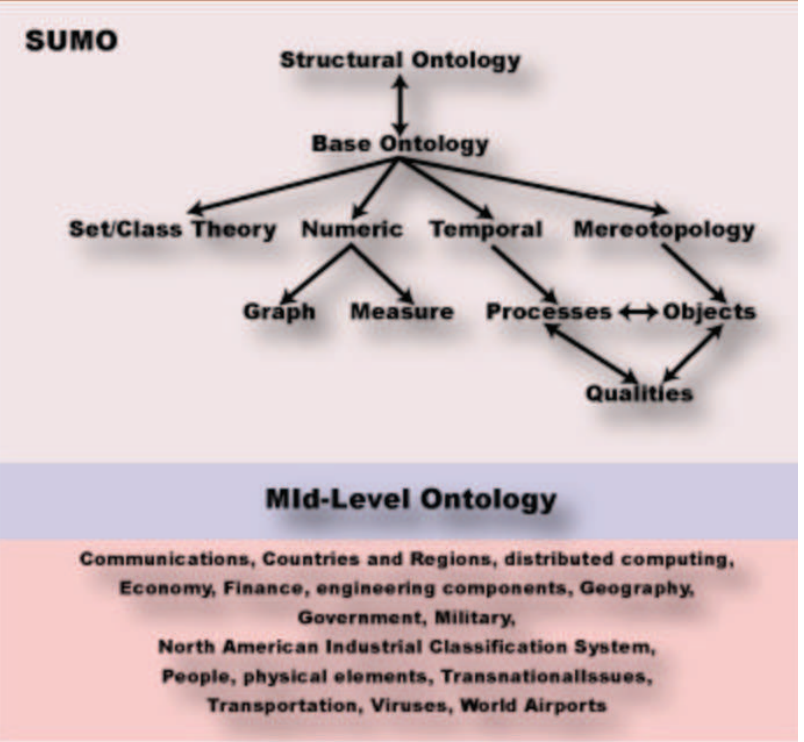

Слика 2. The Suggested Upper Merged Ontology (SUMO) http://www.adampease.org/OP/ 
SUMO онтологија и њене доменске онтологије формирају највећу формалну онтолгију која данас постоји. Појам онтологије у рачунарству и информатици се односи на представљање знања у облику формално дефинисаног система појмова и релација између тих појмова. Главна сврха онтологија у информатици није да буду коришћене као речници или таксономије, већ да учествују у дељењу и вишеструкој употреби знања од стране различитих интелигентних агената и апликација. Зависно од тога који део стварности описују, онтологије могу бити онтологије највишег нивоа (енг. top level ontologies) - када моделују опште концепте, а знање које репрезентују је свеобухватно,систематизовано и применљиво у великом броју апликација. Ако се има у виду да се интелигентни системи баве и представљањем и обрадом знања, јавља се потреба за поновним коришћењем знања неког домена. На овај начин се постиже да се знање које је прикупљено у току решавања једног проблема може поново користи у новим верзијама интелигентног система.

\section{Литература:}

Berners-Lee, Tim, James Hendler, and Ora Lassila. "The semantic web." Scientific american 284.5 (2001): 28-37.

Berners-Lee, Tim, et al. "Creating a Science of the Web." Science 313.5788 (2006): 769-771.

Devedžić, Vladan. "The setting for semantic web-based education." Semantic Web and Education (2006): 71-99.

Giaretta, Pierdaniele, and N. Guarino. "Ontologies and knowledge bases towards a terminological clarification." Towards very large knowledge bases: knowledge building \& knowledge sharing 25 (1995): 32.

Genesereth, Michael R., and Nils J. Nilsson. "Logical foundations of artificial." Intelligence. Morgan Kaufmann 58 (1987).

Grabar, Natalia, Thierry Hamon, and Olivier Bodenreider. "Ontologies and terminologies: Continuum or dichotomy?." Applied ontology 7.4 (2012): 375-386.

Gruber, ThomasR. "Atranslationapproach to portableontologyspecifications." Knowledge acquisition 5.2 (1993): 199-220.

Gruber, Thomas R. "Toward principles for the design of ontologies used for knowledge sharing?." International journal of human-computer studies 43.5-6 (1995): 907-928.

Hendler, Jim, and Tim Berners-Lee. "From the Semantic Web to social machines: A research challenge for Al on the World Wide Web." Artificial Intelligence 174.2 (2010): 156-161. 
Liu, Ling, and M. Tamer Özsu. Encyclopedia of database systems. Vol. 6. Berlin, Heidelberg, Germany: Springer, 2009.

Niles, Ian, and Adam Pease. "Origins of the IEEE standard upper ontology." Working notes of the IJCAI-2001 workshop on the IEEE standard upper ontology. 2001.

Nilsson, Nils J. "Logic and artificial intelligence." Artificial intelligence 47.1-3 (1991): 31-56. Nirenburg, Sergei, and Victor Raskin. Ontological semantics. Mit Press, 2004

Pease, Adam. Ontology: A practical guide. 2011.

Petronijević, Branislav. Istorija novije filozofije. Nolit, 1982.

Staab, Steffen, et al. "Knowledge processes and ontologies." IEEE Intelligent systems 16.1 (2001): 26-34

Sugumaran, Vijayan, and Veda C. Storey. "Ontologies for conceptual modeling: their creation, use, and management." Data \& knowledge engineering 42.3 (2002): 251-271

Vujaklija, Milan. "Rečnik stranih reči i izraza." Prosveta Beograd (1970).

\title{
Интернет адресе
}

http://semanticweb.org/wiki/Ontology.html (приступљено 11.06.2016)

http://www.adampease.org/OP/ (приступљено 21.06.2016)

http://www-ksl.stanford.edu/kst/what-is-an-ontology.html (приступљено17.09.2016)

https://www.w3.org/RDF/Metalog/docs/sw-easy (приступљено15.6.2016)

\author{
Sanja Antonić \\ Vesna Šujica \\ Igor Živanović \\ University library "Svetozar Markovic"
}

\section{ONTOLOGY IN PHILOSOPHY AND INFORMATION SCIENCE: POTENTIAL SYNTHESIS OF IMPOSSIBLE}

\section{Summary}

According to some opinins, ontology is central part of methaphysics, field in philosophy, which comes after „physics“, the latter being the study of nature in general. This study being and particulary, what there is, e.g. material objects, minds, persons, 
universals, numbers, facts, etc. Although ontology as a philosophical concept is highly theoretical, it also has practical application in information science and technology, such as ontology engineering. The second sense is used in research on Artificial Intelligence and Knowledge Representation; one of the best known definitions is Tom Gruber's: "An ontology is an explicit specification of a conceptualization." The term is borrowed from philosophy, where an ontology is a systematic account of Existence. For knowledgebased systems, what "exists" is exactly that which can be represented. When the knowledge of a domain is represented in a declarative formalism, the set of objects that can be represented is called the universe of discourse. This set of objects, and the describable relationships among them, are reflected in the representational vocabulary with which a knowledge-based program represents knowledge. Ontology and ontological engineering are expected to play a significance role in future development of telecommunication and web services. The fields of artificial intelligence, the semantic web, systems engineering, software engineering, biomedical informatics, library science and information architecture all create ontologies to limit complexity and to organize information.

Key words: Ontology, Methaphysics, Information Science, Semantic Web, Artificial Inteligence. 